\title{
THE SYSTEMICALLY STRUCTURED ADAPTATION OF A HEAT TRANSFER IN BOILERS
}

\author{
E.V.Toropov, evtor@mail.ru \\ South Ural State University, Chelyabinsk, Russian Federation
}

\begin{abstract}
"When problem is correctly posed, it is already solved", J. Nash, Nobel Laureate.
The article provides a model of heat exchanging processes and burning in the boiler aggregates generated with methods of systems analysis and adapted for the five-step scheme of processes. Conditions of division of all factors and parameters into input, output and control ones for each stage are formulated; communications and boundaries between local systems are defined. The solved task is a stage at mode and design optimization of boiler aggregates under stationary conditions, generally, at average industrial thermal power plants, but it may be applied to boiler aggregates of other types and parameters.
\end{abstract}

Keywords: boiler aggregate; structure; control; heat exchange; system of flows.

\section{Introduction}

When synthesizing systems controlling processes in the boiler aggregate as any technical or technological unit, the object interacts with an external environment in the static or dynamic mode. Its interaction may be quantitatively evaluated through inputs with a vector $X_{i n}(\tau)$ and outputs with vector $Y_{\text {out }}(\tau)$; synthesis of system also methodically belongs to control.

The input controlled variables or perturbations, $X(\tau)$ and controlling variables (controlling influences) $U(\tau)$ form $X_{\text {in }}(\tau)$ collectively.

Perturbing variable (perturbations) $E(\tau)$ are random time-dependent uncontrollable factors based on which hypotheses (assumption) may only be predicted, but not directly measured. Thus, three inputs: observable, but not controlled $X(\tau)$, controlled and observable $U(\tau)$ both unobservable and uncontrollable $E(\tau)$ generate output parameters of the controlled object $Y_{\text {out }}(\tau)$ at any specific time $[1,2]$.

The measuring system allows controlling some variable vectors based on the total of $X(\tau), U(\tau)$ and $Y(\tau)$. In most cases, an actual dimensionality of these vectors is higher than that of their measured values $X_{u}(\tau), U_{u}(\tau)$ and $Y_{u}(\tau)$ as some variables cannot be measured due to the lack of appropriate technical, and some of them cannot be essentially measured.

Additional uncertainty is imposed by measurement errors or accidental perturbations $E(\tau)$ influencing measuring systems $E_{x}(\tau), E_{u}(\tau)$ and $E_{y}(\tau)$. Results of measurements can be generally presented as follows:

$$
\begin{aligned}
& X_{u}(\tau)=\Phi_{x}\left[X(\tau), E_{x}(\tau)\right], \\
& U_{u}(\tau)=\Phi_{u}\left[U(\tau), E_{u}(\tau)\right], \\
& Y_{u}(\tau)=\Phi_{y}\left[Y(\tau), E_{y}(\tau)\right] .
\end{aligned}
$$

where $\Phi_{x}, \Phi_{u}, \Phi_{y}$ - operators of measuring system.

Thus, the control system is based on the following current condition of the object at any specific time:

$$
J=\left\langle X_{u}, U_{u}, Y_{u}\right\rangle \text {. }
$$

This information is always incomplete because of limits of any system and its installation and operation costs.

\section{Proposed solution of problem}

System management is enabled by the remote control device or system of automatic control. Their stable functioning requires both information $J$ and the control objective. In most cases, the control objective may be formally specified by the $Z_{y}$ value of $Z$ functional being an objective function or control criterion

$$
Z_{y}=Z\left[Y_{u}(\tau), U_{u}(\tau), X_{u}(\tau)\right]
$$

Different technical or technical and economic features may be selected as control criteria: e.g. a deviation of temperature of a gas flow at the output of a fire chamber $t_{s l}^{\prime \prime}$ from the set value, violation of the limit value set for surface slagging of the boiler superheater or those of superheated steam temperatures or pressure, etc. Usually, control criteria are developed rather conditionally dependent on the general requirements for operation of the boiler aggregate. In case of profound approach to the control criterion, there is a need to evaluate the task of control according to several quality-varying partial criteria.

For example, control of the boiler aggregate (BA) shall provide:

- specified evaporation capacity $D_{s h}$ at the required superheat parameters $t_{s h}, P_{s h}$ (technological criterion);

- maximal performance coefficient of the boiler aggregate generally determined by fuel consumption and temperature of exit combustion gases (technical and economic criterion);

- the lowest level of harmful emissions into the environment (ecological criterion).

As a rule, each of these partial criteria may be met by a single solution, but difference in their results stipulates the fact that multi-criteria tasks have no definite general solution as control is provided under certain given conditions. 


\section{Теплоэнергетика}

Selection of the criterion for quantitative assessment of alternatives is a crux of the system study concept.

Such criterion shall be expressed in terms of the system control objective; its purpose is recognition of a preferred procedure for BA design and operation or synthesis of its system and structural model (SSM). When solving multi-criteria task, one shall aim to convert it to the one-criterion task, for example, by introduction of the generalized index including all partial criteria. Sometimes, partial criteria are arranged and only the main criterion is taken into consideration. Such "super-criterion" may be generated as a linear combination of modified partial criteria. Here, additional criteria with their weight number are added to the main one. This part of the analysis may also involve the method of expert evaluations.

Therefore, ecological criterion usually comes into conflict with the technical and economic one determined by complete fuel burning in the boiler aggregate as a minimum level of harmful emissions of nitrogen oxides may be accompanied by increased losses due to incomplete burning. Nevertheless, there is a number of the technical design and mode solutions meeting these two requirements; they should be considered separately [3].

According to $[2,4]$, the objective of control or SSM synthesis is provision of the most favorable (maximum or minimum) values of $Z$ functional

$$
\operatorname{Min}(\max ) Z\left[Y_{u}(\tau), U_{u}(\tau), X_{u}(\tau)\right]=Z^{*} .
$$

Under actual SSM operation vectors of control $U_{u}(\tau)$ and output parameters $Y_{u}(\tau)$ may vary only within a certain final value domain that may be formally represented as a system of the following limits:

$$
U_{u}(\tau) \in G_{U}, \quad Y_{u}(\tau) \in G_{Y} .
$$

Here, $G_{U}$ and $G_{Y}$ - closed and limited areas of the vector control and output parameter space. SSM elements of the boiler aggregate have definite limits of admissible pressure, speed, temperature of heat carrier flows, heat fluxes as well as mode and design constraints [5].

SSM synthesis involves the search for such values of vectors $U^{*}{ }_{u}(\tau)$ and $Y^{*}{ }_{u}(\tau)$ to achieve the specified control objective $Z^{*}$ at limited synthesis resources. Generally, the task may be solved with optimization, but one shall consider technical, technological and resource limits to ensure a reduced share of expenses in the production cost. Optimization may also be aimed to the reduced power consumption, improved performance coefficient, prevention of an adverse environmental impact, increased heat transfer coefficient in the SSM element, better weight-anddimensional parameters of the equipment, etc. Thus, the task of the SSM synthesis may be formulated as follows: to find and implement a functional dependence providing the maximum approximation to the set value $Z^{*}$ at available resources of the SSM synthesis:

$$
U_{u}^{*}(\tau)=\varphi\left[Y_{u}(\tau), U_{u}(\tau), X_{u}(\tau), Z^{*}\right] .
$$

The dependence (8) is defined as an algorithm for control of the SSM synthesis as it formulates an accurate instructive rule for achievement of the given purpose in a certain situation (1)-(7). The synthesis task and algorithm become simpler when the task is set as a vector of a known scheduled status. Then, the criterion of optimality of SSM synthesis may be conceived as a functional of an error of the vector of output parameters $\varepsilon(\tau)=\left|Y^{*}{ }_{u}(\tau)-Y_{u}(\tau)\right|$

$$
Z^{*}=Z[\varepsilon(\tau)] \text {. }
$$

This partial control task may be called as a task of SSM synthesis control, in exacter terms - determination of the law for SSM synthesis control at set value $Y^{*}{ }_{u}(\tau)$ and provision of a minimum of criterion $Z^{*}$

$$
U^{*}(\tau)=\varphi[\varepsilon(\tau)] .
$$

\section{Decomposition of the general SSM}

Decomposition of the general SSM of the boiler aggregate GS on local systems may take a form of the $S 1-S 5$ complex with appropriate designation of local systems. They include the system of preparation and supply of burning components $S 1$ to the convection pass $S 5$ at the output of which temperature of exhaust gases $t_{\text {waste }}$ substantially influencing the boiler performance coefficient is measured.

\section{Details of systemically structured adaptation}

The laws of thermodynamics, thermal physics, theory of combustion, fluid dynamics and other fundamental relations determine the type, quantitative relationships and trends of processes within any local system. Quantitative relationships between local systems are described by balance equations of energy, mass and pressure. The system of balance equations establishes the relationship between physical, thermodynamic and consumption parameters of the local systems that provides a predetermined steady BA load.

In practice, modes or external condition variations result in transient system behavior. Switching to a new steady state occurs in a period known as a lag time; it depends on development of inertial processes within the local systems and whole system. Metering lag time enables description of all steady modes within a uniform mathematical model.

A general SSM scheme may include description of local systems as processes with lumped parameters enabling application of ordinary differential or algebraic and transcendental equations. However, when considering processes in the local systems, it is often necessary to apply differential equations for partial derivatives. It relates to description of burning within the BA - S2 intense combustion zone or of a nonuniform speed field within the main portion of the fire chamber of BA - S3 within the framework of heat exchange in the fire chamber; parallel processes are described with the second Kirchhoff's electricity rule [6].

The boundary of each SSM structural element must be determined by the axial line of a transverse 
section of the gas flue in fractions of total length $l_{\text {tot }}$ of gas flues $L_{i}=l_{i} / l_{\text {tot }}$ taking into account configuration of the boiler aggregate. When considering a close configuration, that is, without an explicit horizontal gas flue, the length of a "horizontal" section may be determined based on the distance between mid-points on the planes connecting internal and external angles of gas flue bending.

Thus, $S 1$ is characterized by limits $G_{y}$ at the output: air pressure and temperature, available heat power defined by the fuel consumption and its combustion heat $Q_{i}^{r}$, restricted by humidity, ash and sulfur content in solid fuel.

Limits are influenced by the design of fuel burning facilities and requirement to quality of burning according to incomplete combustion and carbon losses, nitrogen oxide and carbon content and achievable burning temperature.

$$
\begin{aligned}
& X_{S 1} \in\left(W^{r}, A^{r}, S^{r}, t_{s l}, t_{\text {air }}, Q_{\text {low }}^{r}, K_{c, x}\right), \\
& U_{S 1} \in\left(B, \alpha_{\text {burn }}, C_{r}, t_{g}, K_{c, u}\right), \\
& Y_{S 1} \in\left(w_{g}, w_{\text {air }}, t_{\text {ad }}, L_{t}, t_{t}, K_{c, y}\right) .
\end{aligned}
$$

System $S 2$ is an intense combustion zone (ICZ) that can differ in the BA of various arrangement $\left(K_{i}\right)$. Based on the output data from S1, the S2 flow, temperature and combustion product content output signals are formed. The equation also considers heat exchange processes of the flare and furnace gases with involvement of the water steam barrier in heat absorption surfaces with due regard to the ICZ and barrier types [2]. All variants of ICZ design may be reflected in the flare continuity concept that describes heat exchange within the system of three bodies- of two gaseous ones (furnace gas and flare environment) and a solid one (ICZ barrier). In this case, the resultant heat flux is calculated with the Stephane - Boltzmann law with the reduced radiation coefficient $C_{r}$

$$
\begin{aligned}
& X_{S 2} \in\left(w_{g}, w_{\text {air }}, t_{a d}, t_{t}, L_{t}, t_{g}, F_{t}, F_{b}\right), \\
& U_{S 2} \in\left(q_{r e s}, C_{r}, t_{g}^{\prime \prime}, q_{i, b}\right), \\
& Y_{S 2} \in\left(w_{w}, t_{w}, q_{3}, \operatorname{Re}, G r, N u, B u\right),
\end{aligned}
$$

where $R e, G r, N u, B u$-Reynold's, Grashof's, Nusselt's and Bouguer's values.

S3 system is the main portion of the BA fire chamber where fuel residuals are after-burnt and radiant/convection heat transfer to the heat absorption surfaces takes place; these surfaces provide heating and evaporation of the water heat carrier. Actually, the task of mathematical simulation of BA processes is bifurcated from $\mathrm{S} 3$ system; the task becomes conjugate at obtaining solutions of the heat transfer equations. In this case, the task is related to aeromechanics and gaseous heat exchange, whilst water and steam data are considered known and single-valued conditions. The equations of hydrodynamics and heat exchange of the water and steam medium shall be consequently solved with data on aeromechanics and heat exchange in the gaseous medium being considered as single-valued conditions. After reliable data and functional dependences for two flows have been obtained, the conjugate problem may be solved. According to the thermodynamic principles, main characteristics of a gaseous flow $w_{g}, t_{g}$ shall be determined. Its factor and parameter system is as follows

$$
\begin{aligned}
& X_{S 3} \in\left(\operatorname{Re}, G r, N u, B u, w_{g}, t_{g}, \psi\right), \\
& U_{S 3} \in\left(t_{S 3}^{\prime}, w_{g}, G r\right), \\
& Y_{S 3} \in\left(t_{\mathrm{S} 3}^{\prime \prime}, w_{\mathrm{g}}\right) .
\end{aligned}
$$

The main portion of the fire chamber may have variable design according to the general BA configuration. The model of heat and mass exchange may be applied to the exhaust path to reduce the number of process factors and parameters by means of their combining and coupling considerably. Here, the mathematical model considers data of gas flux at the $S 3$ input as single-valued conditions. Characteristics of the water and steam flux have restrictions related to the heat flow to prevent critical heat flux conditions of I and II types as well as violation of the temperature limit of the heat area.

All heat exchange surfaces of the connective flue pipe and their characteristics are combined in $S 4$ system. An essential criterion at selection of boundary between $S 3$ and $S 4$ is the temperature at the fire chamber outlet; the latter is defined by the temperature of slagging start $t_{s l}^{\prime \prime} \approx t_{12}$ for powder-coal BAs [3]. As for oil-gas BAs, technical and economic analysis of strength of metal surfaces of boiler super-heaters and the required conditions of steam generation in $S 3$ plays an important part.

In a basic unit design including connective gas flue of the boiler super-heater only, the boundary of transition to convective $S 5$ portion is determined by temperature $t_{S 4}^{\prime \prime} \leq 0,95 t_{s l}$, while $t_{S 4}^{\prime \prime}$ complies with varying enthalpy of a gas flux in the connective gas flue $\Delta i_{S 4}$. The latter value shall correspond to an increment of steam enthalpy in this section except for heat transferred within the screen. The $S 4$ system design [4] may be based on different schemes; main restrictions at synthesis are as follows: prevention of temperature of formation of stick deposits $t_{1}$ at the beginning and that of dense ash deposit generation $t_{2}$ at the end of $S 4$ as well as of oxidation of tube sheets in the air heater.

$$
\begin{aligned}
& X_{S 4} \in\left(t_{S 3}^{\prime \prime}, \rho w^{\prime}, K_{\mathrm{S} 4}, G_{r}\right), \\
& U_{S 4} \in\left(t_{1}, t_{2}, \Delta i_{\mathrm{sl}}\right), \\
& Y_{S 4} \in\left(t_{S 4}^{\prime \prime}, \rho w^{\prime \prime}\right) .
\end{aligned}
$$

All heat exchange surfaces of the convective gas flue are integrated in $S 5$ system; its input factors are mass flux density at the input $\rho w_{S 4}^{\prime \prime}$, arrangement factor $K_{S 5}$ and temperature of a gas flow at the input $t_{S 5}^{\prime}=t_{S 4}^{\prime \prime}$ : 


$$
\begin{aligned}
& X_{S 5} \in\left(\rho w_{S 4}^{\prime \prime}, t_{S 4}^{\prime \prime}, K_{S 5}\right), \\
& U_{S 5} \in\left(K_{S 5}, t_{w}^{\prime}, t_{w}^{\prime \prime}\right), \\
& Y_{S 5} \in\left(t_{\text {waste }}, q_{2}, \eta_{B A}\right) .
\end{aligned}
$$

The laws of thermodynamics, thermal physics, theory of combustion, fluid dynamics and other fundamental relations determine the type, quantitative relationships and trends of processes within any local system. Quantitative relationships between local systems are described by balance equations of energy, mass and pressure. The system of balance equations establishes the relationship between physical, thermodynamic and consumption parameters of the local systems that provides a predetermined steady BA load.

In practice, modes or external condition variations result in transient system behavior. Switching to a new steady state occurs in a period known as a lag time; it depends on development of inertial processes within the local systems and whole system. Metering lag time enables description of all steady modes within a uniform mathematical model.

A general SSM scheme may include description of local systems as processes with lumped parameters enabling application of ordinary differential or algebraic and transcendental equations. However, when considering processes in the local systems, it is often necessary to apply differential equations for partial derivatives. It relates to description of burning within the BA - S2 intense combustion zone or of a nonuniform speed field within the main portion of the fire chamber of BA - S3 within the framework of heat exchange in the fire chamber; parallel processes are described with the second Kirchhoff's electricity rule [6].

\section{Conclusion}

The developed system model of heat exchanging processes within the BA (11)-(25) enables optimization of aggregate parameters at implementing technical solutions in the steady-state mode when varying the type and characteristics of burning components and other mode and design factors and parameters.

\section{References}

1. Norman S. Nise. Control Systems Engineering, [7th Revised Edition]. USA, John Wiley \& Sons, 2015. $944 \mathrm{p}$.

2. Jones J.C. Combustion Science: Principles and Practice. Newtown, N.S.W.: Millennium Books, 1993. $306 \mathrm{p}$.

3. Roslyakov P.V. Metody zashchity okruzhayushchey sredy: uchebnik dlya vuzov [Methods of Environmental Protection: Textbook for Higher Schools]. Moscow, Publ. of MEI, 2007. 336 p.

4. Bogomolov V.V., Artem'eva N.V., Alekhnovich A.N. et al. Energeticheskie ugli vostochnoy chasti Rossii i Kazakhstana: spravochnik [Energy Coal of Eastern Part of Russia and Kazakhstan: Reference book]. Chelyabinsk, UralVTI, 2004. 304 p.

5. Parshin A.A., Mitor V.V., Bezgreshnov A.N. et. al. Teplovye skhemy kotlov [Thermal Circuits of Boilers]. Moscow, Mashinostroenie Publ., 1987. 224 p.

6. Toropov E.V. [Thermal Problems at Implementation of Alternative Pyro Metallurgy]. Teplofizika $i$ energetika: konferentsiya $s$ mezhdunarodnym uchastiem: sbornik dokladov [Thermal Physics and Energy: International Conference: a Book of Reports]. Ekaterinburg, UrFU, 2013, pp. 577-580.

Received 3 March 2016

Удк 621.18. 536.24

DOI: $10.14529 /$ power160103

\title{
СИСТЕМНО СТРУКТУРИРОВАННАЯ АДАПТАЦИЯ ТЕПЛОПЕРЕДАЧИ В КОТЛАХ
}

\section{E.B. Торопов}

\author{
Южно-Уральский государственный университет, г. Челябинск
}

\begin{abstract}
Представлена модель процессов теплообмена и горения в котельных агрегатах, разработанная методами системного анализа и адаптированная к пятиступенчатой схеме процессов. Для каждой из ступеней сформулированы условия разделения всех факторов и параметров на входные, выходные и факторы управления, определены связи и границы между локальными системами. Решенная задача является этапом при режимной и конструктивной оптимизации котельных агрегатов в стационарных условиях, в основном промышленных ТЭС средних параметров, но может быть распространена на котельные агрегаты других типов и параметров.
\end{abstract}

Ключевые слова: котельный агрегат, структура, управление, теплообмен, система потоков. 


\section{Лumepamypa}

1. Norman S. Nise. Control systems engineering / Norman S. Nise. - 7th Revised edition. - USA: John Wiley \& Sons, 2015. - $944 p$.

2. Jones, J.C. Combustion science: principles and practice / J.C. Jones. - Newtown, N.S.W.: Millennium Books, 1993. - 306 p.

3. Росляков, П.В. Методы защчиты окружающей среды: учеб. для вузов / П.В. Росляков. - М: Издат. дом МЭИ, 2007. - 336 с.

4. Энергетические угли восточной части России и Казахстана: справ. / В.В. Богомолов, Н.В. Артемьева, А.Н. Алехнович и др. - Челябинск, УралВТИ, 2004. - 304 c.

5. Паршин, А.А. Тепловые схемы котлов / А.А. Париин, В.В. Митор, А.Н. Безгрешнов. - М.: Машиностроение, 1987. - 224 c.

6. Торопов, Е.В. Теплофизические проблемы внедрения альтернативной пирометаллургии / Е.В. Торопов // Теплофизика и энергетика: конференция с международным участием: сб. докл. - Екатеринбург: УрФУ, 2013. - C. 577-580.

Торопов Евгений Васильевич, д-р техн. наук, профессор, заслуженный деятель науки и техники РФ, профессор кафедры «Промышленная теплоэнергетика», Южно-Уральский государственный университет, г. Челябинск; evtor@mail ru.

Поступила в редакцию 3 марта 2016 г.

\section{ОБРАЗЕЦ ЦИТИРОВАНИЯ}

Toropov, E.V. The Systemically Structured Adaptation of a Heat Transfer in Boilers / E.V. Toropov // BecTник ЮУрГУ. Серия «Энергетика». - 2016. - Т. 16, № 1. - C. 19-23. DOI: 10.14529/power160103

\section{FOR CITATION}

Toropov E.V. The Systemically Structured Adaptation of a Heat Transfer in Boilers. Bulletin of the South Ural State University. Ser. Power Engineering, 2016, vol. 16, no. 1, pp. 19-23. DOI: 10.14529/power160103 